\title{
Freshwater crustaceans of Bykovsky Peninsula and neighboring territory (Northern Yakutia, Russia)
}

\author{
Пресноводные ракообразные Быковского полуострова \\ и прияегающих территорий (Северная Якутия, Россия)
}

\author{
A.A. Novichkova ${ }^{1,2}$, A.A. Kotov ${ }^{1 *}$, E.S. Chertoprud ${ }^{1,2}$ \\ А.А. Новичкова ${ }^{1,2}{ }^{*}$, А.А. Котов ${ }^{1}$, Е.С. ЧертопруА ${ }^{1,2}$
}

\footnotetext{
${ }^{1}$ A.N. Severtsov Institute of Ecology and Evolution, Leninsky Prospect 33, Moscow 119071, Russia.

${ }^{2}$ Department of Hydrobiology, Biological Faculty, M.V. Lomonosov Moscow State University, Leninskie Gory, Moscow 119991, Russia.

${ }^{1}$ Институт проблем экологии и эволюции им. А.Н. Северцова РАН, Ленинский проспект, д. 33, Москва 119071, Россия.

${ }^{2}$ Кафедра гидробиологии, Московский государственный университет им. М.В. Ломоносова, Ленинские горы, Москва 119991, Россия.

*Corresponding author: alexey-a-kotov@yandex.ru
}

KEY WORDS: Crustacea, Cladocera, Copepoda, fauna, biodiversity.

КЛЮЧЕВЫЕ СЛОВА: Crustacea, Cladocera, Copepoda, фауна, биоразнообразие.

ABSTRACT. Numerous water bodies in the northern portion of Eastern Siberia are poorly studied both in their species composition and community structure. The aim of this study is to provide an inventory of the freshwater microcrustaceans of Bykovsky Peninsula and neighboring territory (North Yakutia, Russia) and to analyse the community structure in the studied water bodies with the aim of revealing separate environmental factors affecting it. In toto, we identified 19 copepod species (belonging to 14 genera) and 16 branchiopod species (12 genera). Seven species were first records from this area of NE Siberia, namely calanoid copepods Acanthodiaptomus denticornis, Arctodiaptomus wierzejskii cyclopoid copepods Acanthocyclops venustus, Diacyclops crassicaudis, D. languidoides; cladocerans Eurycercus cf. glacialis, Pleuroxus cf. trigonellus. The fauna of Bykovsky Peninsula and neighbouring territory is very poor and mainly represented by eurybiotic taxa with wide Palearctic or Holarctic ranges. Differences in community structure of different water bodies could be explained mainly by abiotic preferences (i.e. in conductivity/salinity and temperature) of dominant species.

How to cite this article: Novichkova A.A., Kotov A.A., Chertoprud E.S. 2020. Freshwater crustaceans of Bykovsky Peninsula and neighboring territory (Northern Yakutia, Russia) // Arthropoda Selecta. Vol.29. No.1. P.1-12. doi: 10.15298/arthsel. 29.1.01

РЕЗЮМЕ. Многочисленные водоемы северной части Восточной Сибири плохо изучены как в части их фауны, так и структуры сообществ. Целью данной работы было провести инвентаризацию видового состава микроскопических ракообразных Быковского полуострова и его окрестностей (Cеверная Якутия, Российская Федерация) и проана- лизировать структуру сообществ с целью выявить основные факторы среды, определяющие последнюю. Всего было идентифицировано 19 видов Copepoda (14 родов) и 16 видов Branchiopoda (12 родов). Среди них, семь видов были впервые найдены в этом регионе северной части Восточной Сибири, а именно два вида каляноид (Acanthodiaptomus denticornis, Arctodiaptomus wierzejskii), три вида циклопоид (Acanthocyclops venustus, Diacyclops crassicaudis, D. languidoides) и два вида кладоцер (Eurycercus cf. glacialis, Pleuroxus cf. trigonellus). Фауна района очень бедна и в основном представлена эврибионтными видами с широкими палеарктическими или голарктическими ареалами. Различия в структуре сообществ в различных водоемах могут быть объяснены различными абиотическими предпочтениями (в т.Ч., в части удельной электропроводности/солености и температуры) доминантных видов.

\section{Introduction}

Numerous water bodies of Eastern Siberia, especially in its northern portion, are poorly studied in terms of species composition and community structure. Few papers were published on the microscopic crustaceans of this vast part of Russia [Sars, 1898; Rylov, 1928; Behning, 1942; Urban, 1949; Vekhov, 1989]. During the last decade several detailed publications on zooplankton from a few regions of northern Yakutia have appeared, i.e. Yana River basin [Sobakina, 2013; Trofimova et al., 2018], Indigirka River basin [Frolova et al., 2016] and Anabar River basin [Sobakina et al., 2009; Frolova et al., 2013]. All such papers were based on data from a very limited number of water bodies. Moreover, author's identifications need a substantial 
re-evaluation keeping in mind recent progress in the taxonomy of different microcrustaceans [Korovchinsky et al., 2012; Kotov, 2015].

The best explored region is the Lena River Delta, one of the largest deltas in the world [Are, Reimbitz, 2000]. Its total area is almost $30.000 \mathrm{~km}^{2}$ and there are more than 29.000 lakes within this area [Bolshiyanov et al., 2013]. Although zooplankton investigations in the Lena River Delta date back to a Russian Polar expeditions at the beginning of the 20th century (19011903), the information on the structure and functioning of zooplankton communities within this large region is limited, although first data on the zooplankton were published already by Rylov [1928] and Behning [1942]. The general list of fauna, based on their data, included about 50 species and forms.

Further analysis of the material collected throughout the Lena River from Yakutsk prior to the beginning of the delta, and also in Olenekskaya and Tumatskaya channels of the delta, the bay of Tiksi, the Oleneksky Gulf and Neyelov's Gulf, expanded this list to 75 taxa [Pirozhnikov, Shulga, 1957]. The studies of the zooplankton in the Lena River Delta, first of all, covered the largest river channels - Oleneksky, Bykovsky, Tumatskaya and Trofimovskaya [Behning, 1942; Urban, 1949; Pirozhnikov, Shulga 1957; Serkina, 1969; Abramova, 1996; Nikanorov et al., 2011; Nigamatzyanova et al., 2014; 2016] or brackish estuarine areas around the delta [Virketis, 1932; Lutsik et al., 1981; Sorokin, Sorokin, 1996; Abramova, Tuschling, 2005]. It was noted that the structure of zooplankton of the Lena River is characterized by absence of some representatives of Copepoda and Cladocera, widespread in plankton of other large rivers of Siberia (for example, Yenisei and Ob) [Nigamatzyanova et al., 2014]. It was shown that rotifers are most numerous in the zooplankton of the channels. In general, the planktonic community of channels is characterized by low species richness and abundance [Nigamatzyanova et al. 2014]. The structure of the domination is unstable and varies considerably both on a time span of several years, and within one season [Nikanorov et al. 2011].

Compared to other arctic territories of Russia, information on the pelagic fauna of lakes, ponds and wetlands in the Lena River Delta is rather detailed (e.g. Rylov, 1928; Kerer, 1968; Abramova, 1996, 2003;
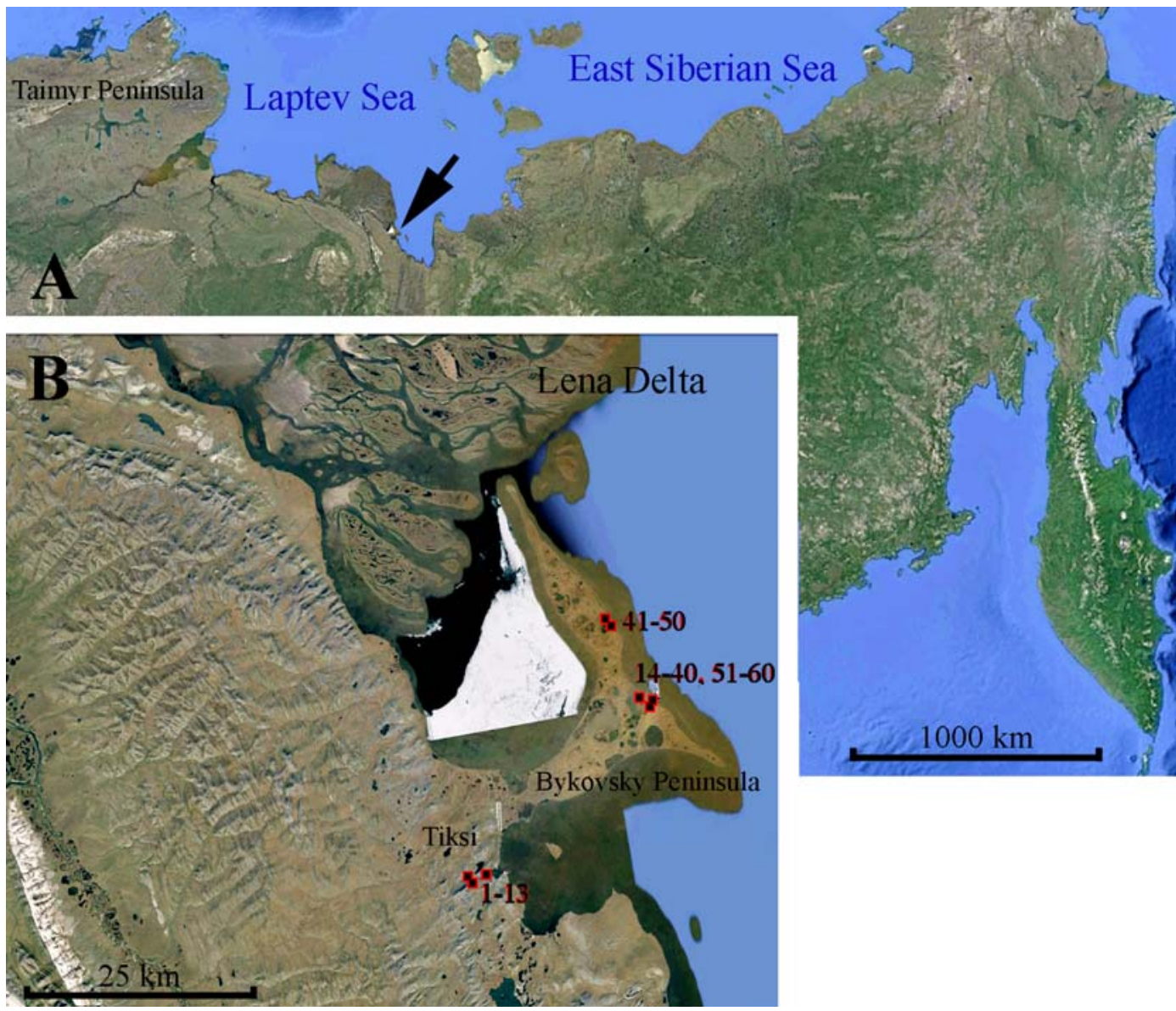

Fig. 1. Map of Eastern Siberia with position of the Lena Delta (A, arrow) and three areas of sampled stations (1-60) in the vicinities of Tiksi and on Bykovsky Peninsula (B). Initial maps are from Google Earth (https://www.google.ru/intl/ru/earth/).

Рис. 1. Карта Восточной Сибири с отмеченным положением дельты Лены (А, стрелка), а также три района отбора проб (1-60) в окрестностях Тикси и на Быковском полуострове (В). Исходная карта взята с портала Google Earth (https://www.google.ru/intl/ru/ earth/). 
Abramova, Sokolova, 1999; Abramova et al., 2009; 2017; Vishnyakova, Abramova, 2009; Nigamatzyanova et al., 2014; 2016, etc.). The fauna of such water bodies is found to be much richer than that of the Lena River Delta [Kerer, 1968]. It was also shown that the fauna of standing waters of a seaside part of the delta is slightly poorer than that in central and southern portions [Serkina, 1969]. Our knowledge on the water communities of the Lena River delta has been slowly but steadily growing during the last decades. The most recent and comprehensive study of the zooplankton of the Lena River Delta has resulted in the list of 125 zooplankton taxa belonging to Rotifera (67) and Arthropoda (58) [Abramova et al., 2017].

The aim of this study is to provide an inventory of the freshwater microcrustacean fauna of Bykovsky Peninsula and neighboring territory, closely located to the Lena Delta (Fig. 1A). We believe that our study of this remote and uninvestigated area will improve the knowledge of the diversity of microcrustacean species in the water bodies across the northeastern part of Siberia. We also aimed to analyse the community structure in the studied water bodies and to evaluate the main environmental factors affecting it.

\section{Material and methods}

The samples were collected in August 2015 in 60 shallow water bodies in the northern part of Yakutia (Sakha Republic, Russia): near the Settlement of Tiksi (Table 1, Fig. 1B: 1-13) and on Bykovsky Peninsula (14-60). Water bodies near Tiksi are tundra ponds and puddles with a moderate anthropogenic influence. Domestic and construction waste is present in littoral zone, the water in some cases is moderately polluted with fuel products. The anthropogenic influence in such water bodies was not estimated quantitatively, but its absence or presence was noted. Bykovsky Peninsula is a permafrost territory with typical water bodies of the "polygonal tundra" [Washburn, 1979; Veremeeva, Gubin, 2009]: ponds or mires in the centers of the polygons; ditches above the ice wedges; few large, shallow thermokarst

Table 1. List of water bodies and their main characteristics. Таблица 1. Список исследованных водоемов и их основные характеристики.

\begin{tabular}{ccccccccccc}
\hline No & AREA & N & E & DEPTH & TEMP & PH & SALT & ORP & COND & TDS \\
\hline $\mathbf{0 1}$ & TIK & 71.63756 & 128.84471 & 0.15 & & & & & & \\
$\mathbf{0 2}$ & TIK & 71.63936 & 128.84564 & 0.5 & & & & & & \\
$\mathbf{0 3}$ & TIK & 71.63968 & 128.8419 & & & & & & & \\
$\mathbf{0 4}$ & TIK & 71.64091 & 128.84087 & & & & & & & \\
$\mathbf{0 5}$ & TIK & 71.64151 & 128.8438 & 0.2 & & & & & & \\
$\mathbf{0 6}$ & TIK & 71.63639 & 128.84198 & & & & & & & \\
$\mathbf{0 7}$ & TIK & 71.64159 & 128.84276 & & & & & & & \\
$\mathbf{0 8}$ & TIK & 71.63631 & 128.84201 & & & & & & & \\
$\mathbf{0 9}$ & TIK & 71.63524 & 128.84177 & & & & & & & \\
$\mathbf{1 0}$ & TIK & 71.63501 & 128.84239 & & & & & & & \\
$\mathbf{1 1}$ & TIK & 71.63412 & 128.84486 & & & & & & & \\
$\mathbf{1 2}$ & TIK & 71.63678 & 128.86964 & & & & & & & \\
$\mathbf{1 3}$ & TIK & 71.63659 & 128.84352 & 0.2 & & & & & & \\
$\mathbf{1 4}$ & MB & 71.78642 & 129.40312 & 0.7 & 10.6 & 6.56 & 0 & 362 & 34 & 21 \\
$\mathbf{1 5}$ & MB & 71.7863 & 129.40292 & 0.7 & 9.5 & 6.55 & 0 & 322 & 0 & 0 \\
$\mathbf{1 6}$ & MB & 71.78641 & 129.40265 & 0.2 & 9.3 & 7.07 & 0 & 327 & 0 & 0 \\
$\mathbf{1 7}$ & MB & 71.78639 & 129.40186 & 0.3 & 9.6 & 6.74 & 0 & 0 & 0 & 0 \\
$\mathbf{1 8}$ & MB & 71.7866 & 129.40101 & 0.2 & 10.7 & 6.26 & 11 & 148 & 27 & 16 \\
$\mathbf{1 9}$ & MB & 71.78674 & 129.40062 & 0.5 & 10.0 & 5.95 & 20 & 149 & 41 & 28 \\
$\mathbf{2 0}$ & MB & 71.78687 & 129.40035 & 0.7 & 11.8 & 6.23 & 12 & 120 & 33 & 22 \\
$\mathbf{2 1}$ & MB & 71.78702 & 129.40028 & & 9.5 & 5.76 & 15 & 140 & 31 & 20 \\
$\mathbf{2 2}$ & MB & 71.78702 & 129.39961 & & 9.9 & 5.98 & 11 & 156 & 21 & 20 \\
$\mathbf{2 3}$ & MB & 71.78703 & 129.39934 & & 8.3 & 5.73 & 33 & 106 & 66 & 44 \\
$\mathbf{2 4}$ & MB & 71.78718 & 129.39926 & 0.2 & 8.3 & 5.80 & 0 & 100 & 0 & 0
\end{tabular}


Table 1 (continued). Таблица 1 (продолжение).

\begin{tabular}{|c|c|c|c|c|c|c|c|c|c|c|}
\hline No & AREA & $\mathbf{N}$ & $\mathbf{E}$ & DEPTH & TEMP & $\mathbf{P H}$ & SALT & ORP & COND & TDS \\
\hline 25 & $\mathrm{MB}$ & 71.78712 & 129.39755 & & 8.5 & 5.90 & 104 & 88 & 214 & 110 \\
\hline 26 & MB & 71.78721 & 129.39703 & & 9.5 & 5.66 & 27 & 70 & 46 & 34 \\
\hline 27 & $\mathrm{MB}$ & 71.79087 & 129.38036 & 0.1 & 11.5 & 5.26 & 8 & 202 & 31 & 15 \\
\hline 28 & $\mathrm{MB}$ & 71.7911 & 129.38016 & 0.2 & 10.3 & 4.82 & 0 & 186 & 0 & 0 \\
\hline 29 & MB & 71.79108 & 129.38022 & & 8.3 & 2.77 & 0 & 190 & 0 & 0 \\
\hline 30 & MB & 71.79111 & 129.37953 & 0.5 & 9.6 & 5.10 & 16 & 164 & 27 & 21 \\
\hline 31 & $\mathrm{MB}$ & 71.78645 & 129.39719 & 0.7 & 9.5 & 7.52 & 34 & 205 & 67 & 44 \\
\hline 32 & $\mathrm{MB}$ & 71.78407 & 129.40381 & & & & & & & \\
\hline 33 & MB & 71.78252 & 129.40111 & 0.3 & & & & & & \\
\hline 34 & $\mathrm{MB}$ & 71.78204 & 129.39914 & & 8.1 & 4.22 & 32 & 180 & 66 & 44 \\
\hline 35 & $\mathrm{MB}$ & 71.78423 & 129.39674 & & 8.0 & 4.08 & 17 & 175 & 33 & 23 \\
\hline 36 & $\mathrm{MB}$ & 71.78511 & 129.39992 & & & & & & & \\
\hline 37 & MB & 71.78551 & 129.39653 & 0.3 & & & & & & \\
\hline 38 & $\mathrm{MB}$ & 71.78472 & 129.39511 & 0.4 & 8.3 & 5.21 & 0 & 181 & 0 & 0 \\
\hline 39 & $\mathrm{MB}$ & 71.78382 & 129.39682 & 0.2 & 7.8 & 4.22 & 11 & 219 & 22 & 14 \\
\hline 40 & $\mathrm{MB}$ & 71.78329 & 129.39862 & & 7.9 & 5.06 & 16 & 181 & 30 & 19 \\
\hline 41 & UM & 71.85961 & 129.34065 & & 8.7 & 5.22 & 177 & 100 & 344 & 228 \\
\hline 42 & UM & 71.85938 & 129.33861 & & 9.1 & & 164 & 126 & 338 & 228 \\
\hline 43 & UM & 71.85928 & 129.33788 & & 9.1 & & 205 & 127 & 415 & 269 \\
\hline 44 & UM & 71.85928 & 129.33707 & & 8.7 & & 170 & 116 & 346 & 229 \\
\hline 45 & UM & 71.85979 & 129.33681 & & 9.3 & & 223 & 56 & 461 & 307 \\
\hline 46 & UM & 71.85979 & 129.33482 & & 8.2 & & 284 & -30 & 556 & 376 \\
\hline 47 & UM & 71.85995 & 129.33488 & & & & & & & \\
\hline 48 & UM & 71.86027 & 129.3349 & & & & & & & \\
\hline 49 & UM & 71.86027 & 129.33514 & & & & & & & \\
\hline 50 & UM & 71.86101 & 129.33803 & & 9.0 & & 344 & 111 & 688 & 457 \\
\hline 51 & $\mathrm{MB}$ & & & & & & & & & \\
\hline 52 & MB & 71.77942 & 129.41396 & & 12.8 & & 34 & & 66 & 39 \\
\hline 53 & MB & 71.77934 & 129.41415 & & 13.3 & & 25 & & 82 & 40 \\
\hline 54 & MB & 71.78687 & 129.38808 & & 14.2 & & 9 & & 0 & 17 \\
\hline 55 & $\mathrm{MB}$ & 71.7868 & 129.38608 & 0.2 & 14.8 & & 0 & & 14 & 0 \\
\hline 56 & $\mathrm{MB}$ & 71.78629 & 129.38483 & 0.2 & 14.8 & & 10 & & 21 & 12 \\
\hline 57 & $\mathrm{MB}$ & 71.78607 & 129.38023 & 0.2 & 13.0 & & 20 & & 22 & 22 \\
\hline 58 & MB & 71.78567 & 129.37704 & 0.2 & 14.2 & & 0 & & 0 & 0 \\
\hline 59 & $\mathrm{MB}$ & 71.78523 & 129.37421 & & 14.2 & & 9 & & 23 & 14 \\
\hline 60 & MB & 71.78568 & 129.37233 & & 12.5 & & 0 & & 0 & 0 \\
\hline
\end{tabular}

Abbreviations for regions: TIK — vicinities of settlement of Tiksi; MB — Mamontoviy Basagasa Alas, Bykovsky Peninsula; UM — Usun-Mas Alas, Bykovsky Peninsula.

Аббревиатуры для районов: ТІК — окрестности поселка Тикси; МВ — Алас Мамонтовый Басагаса, Быковский полуостров; $\mathrm{UM}$ - Алас Усун-Мас, Быковский полуостров. 
Table 2. List of Cladocera and Copepoda species recorded in the vicinities of Tiksi and on Bykovsky Peninsula in August 2015, and number of water bodies in which each species was found.

Таблица 2. Список видов Cladocera и Copepoda, найденных в окрестностях поселка Тикси и на Быковском полуострове в августе 2015 г., а также число водоемов, в которых они были найдены.

\begin{tabular}{|c|c|c|}
\hline Taxa & & $\begin{array}{l}\text { Frequency } \\
\text { (No of water bodies) }\end{array}$ \\
\hline \multicolumn{3}{|l|}{ COPEPODA } \\
\hline \multirow[t]{11}{*}{ Cyclopoida } & Acanthocyclops venustus (Norman et Scott, 1906) & 12 \\
\hline & Cyclops abyssorum (Sars, 1863) & 7 \\
\hline & Cyclops cf. strenuus Fischer, 1851 & 12 \\
\hline & Cyclops kolensis Lilljeborg, 1901 & 2 \\
\hline & Diacyclops crassicaudis (Sars, 1863) & 2 \\
\hline & Diacyclops languidoides (Lilljeborg, 1901) & 11 \\
\hline & Eucyclops sp. & 1 \\
\hline & Megacyclops gigas (Claus 1857) & 16 \\
\hline & Megacyclops viridis (Jurine, 1820) & 11 \\
\hline & Mesocyclops leuckartii (Claus, 1857) & 1 \\
\hline & Paracyclops sp. & 1 \\
\hline \multirow[t]{7}{*}{ Calanoida } & Acanthodiaptomus denticornis (Wierzejski, 1887) & 3 \\
\hline & Arctodiaptomus bacillifer (Koelbel, 1885) & 1 \\
\hline & Arctodiaptomus wierzejskii (Richard, 1888) & 9 \\
\hline & Eurytemora lacustris (Poppe, 1887) & 3 \\
\hline & Heterocope borealis (Fischer, 1851) & 20 \\
\hline & Leptodiaptomus angustilobus (Sars, 1898) & 1 \\
\hline & $\begin{array}{l}\text { Mixodiaptomus theeli (Lilljeborg in Guerne et Richard, } \\
\text { 1889) }\end{array}$ & 10 \\
\hline Harpacticoida & Canthocamptus glacialis Lilljeborg, 1902 & 14 \\
\hline \multicolumn{3}{|l|}{ CLADOCERA } \\
\hline \multirow[t]{2}{*}{ Daphnidae } & Daphnia middendorffiana Fischer, 1851 & 13 \\
\hline & Daphnia cf. pulex Leydig, 1860 & 26 \\
\hline Bosminidae & Bosmina cf. longispina Leydig, 1860 & 4 \\
\hline \multirow[t]{2}{*}{ Eurycercidae } & Eurycercus cf. glacialis Lilljeborg, 1887 & 3 \\
\hline & Eurycercus lamellatus (O.F. Müller, 1776) & 4 \\
\hline \multirow[t]{6}{*}{ Chydoridae } & Acroperus harpae (Baird, 1834) & 1 \\
\hline & Alona cf. affinis (Leydig, 1860) & 2 \\
\hline & Alona guttata Sars, 1862 & 5 \\
\hline & Alonella exigua (Lilljeborg, 1853) & 6 \\
\hline & Chydorus cf. sphaericus (O.F. Müller, 1776) & 26 \\
\hline & Pleuroxus cf. trigonellus (O.F. Müller, 1776) & 1 \\
\hline Polyphemidae & Polyphemus cf. pediculus (Linnaeus, 1761) & 6 \\
\hline
\end{tabular}

stagnant lakes and those originated as creek impoundments. Such water bodies could not be subdivided into discrete types (i.e. in their size).

At each site, zooplankton samples were collected qualitatively by hauling a plankton net (diameter $0.2 \mathrm{~m}, 50 \mu \mathrm{m}$ mesh) through the water column, engaging the upper layer of the bottom with the detached sediment filtered through the net up to the surface. The samples were preserved with $96 \%$ ethanol. All the samples were taken from the shore. Environmental variables such as water temperature, $\mathrm{pH}$, salinity, conductivity, TDS (total dissolved solids) and ORP (oxidation reduction potential) were measured by AMT03R meter (Amtast USA Inc.) only from the water bodies of Bykovsky Peninsula, but not from Tiksi region (Table 1). 

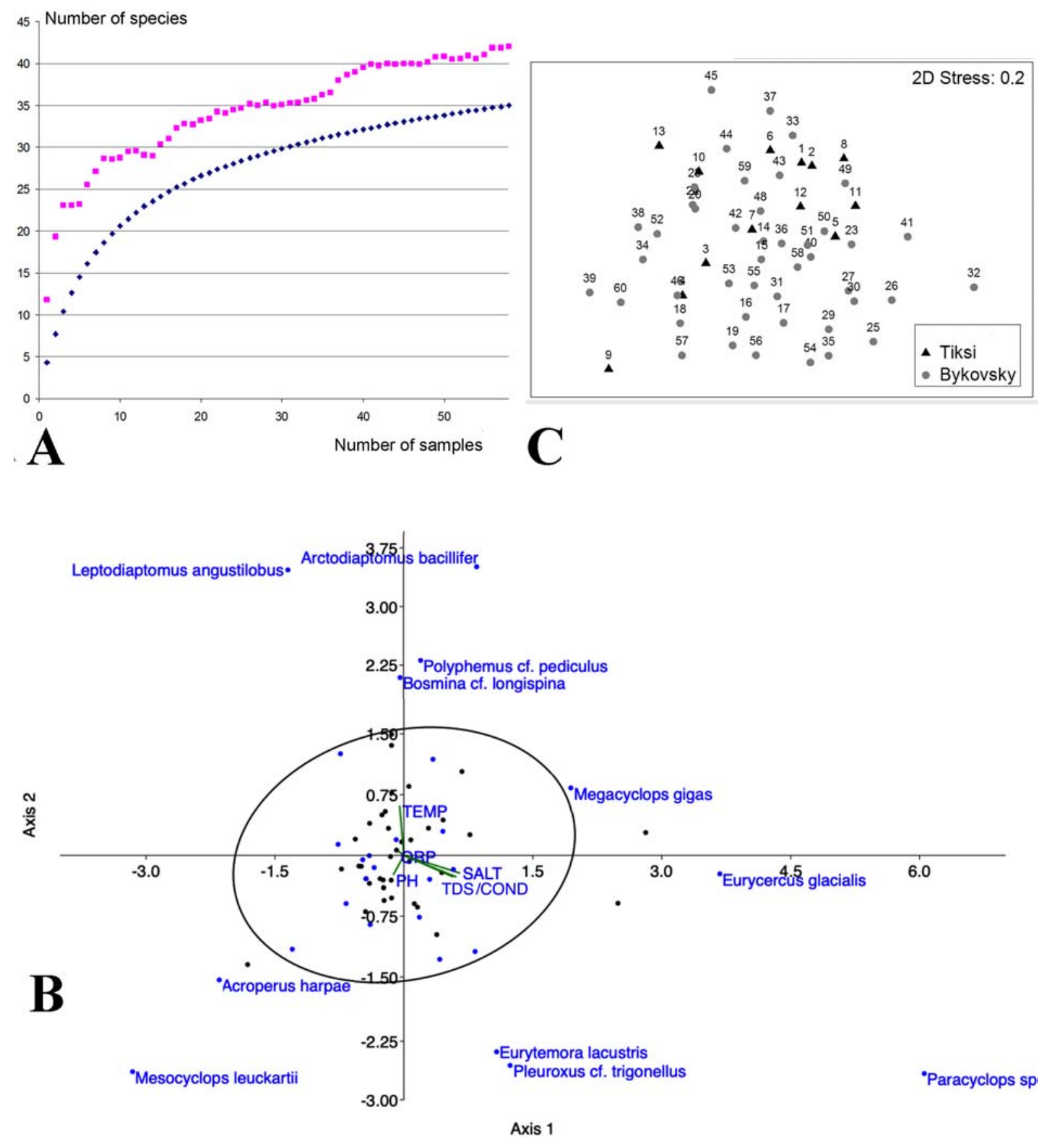

Fig. 2. Analysis of the microcrustacean fauna and communities in the water bodies in the vicinities of Tiksi and on Bykovsky Peninsula. A - species (Cladocera and Copepoda) accumulation curves depending on the number of analyzed samples from Bykovsky Peninsula and its vicinities: empiric (lower blue dots) and estimated (upper red dots) curves; B - results of CCA of the microcrustacean communities in the studied water bodies on Bykovsky Peninsula (species indicated only outside the $95 \%$ cînfidence ellipse area); C MDS ordination of waterbodies from different localities (Tiksi and Bykovsky) according the species composition.

Рис. 2. Анализ фауны и структуры сообществ микроскопических ракообразных водоемов окрестностей Тикси и Быковского полуострова. А - кумулятивная кривая накопления видов (Cladocera и Copepoda) в зависимости от числа проб с Быковского полуострова и прилегающих районов: эмпирическая (синие точки, нижняя) и модельная (красные точки, верхняя) кривые; В результат анализа канонических соответствий (CСA) сообществ микроскопических ракообразных в исследованных водоемах Быковского полуострова (названия указаны только для видов не входящих в 95\% доверительную область); C - MDS-шкалирование водоемов из разных участков исследованной территории (Тикси и Быковский) по видовому составу. 
Preliminary species identification and counting was carried out in Bogorov counting chambers; the total numbers of Cladocera and Copepoda were recorded. The qualitative data was used to reveal dominant and rare species and the ratio of species in the community. Statistical analyses performed for qualitative data, i.e. considered only presence or absence of species. High power microscope Olympus CX41 was used for accurate crustacean identification followed both standard taxonomic treatises [Rylov, 1948; Borutsky, 1952; Dahms et al., 2006; Alekseev, Tsalolikhin, 2010] and recent taxonomic revisions [Sinev, 2002, 2009; Kotov, Bekker, 2016; Garibian et al., 2018].

For estimation of the contribution of the identified species to the potential species pool of the studied area, the accumulation curves of the number of species were plotted depending on the number of samples analyzed. We used the computer package EstimateS [Colwell, 2013] to estimate species richness of the cladocerans and copepods in the region.

A canonical correspondence analysis (CCA) was used to reveal the impact of environmental variables on the invertebrate community. The analysis was performed using PAST software [Hammer et al., 2001] for qualitative data on the water bodies of Bykovsky Peninsula (sites 14-60). The whole species list, including both rare and dominant species was applied.

To represent the faunistic relationships among water bodies from different localities in low-dimensional space, a non-metric multidimensional scaling (nMDS) ordination was performed using PRIMER software [Clarke, Gorley, 2001]. The faunal similarity was estimated using the Kulczynski index $(\mathrm{K})$ for the qualitative data: $\mathrm{K}=(\mathrm{M} / \mathrm{N} 1+\mathrm{M} / \mathrm{N} 2) / 2$, where N1 and N2 are the total numbers of taxa present in the compared lists and $\mathrm{M}$ is the number of common taxa. This index is independent of joint absence and is moderately sensitive to differences in the total length of the compared lists, making it preferential for potentially incomplete data [Clarke, Warwick, 2001].

\section{Results}

We identified 35 crustacean species and taxa: 19 copepod species (belonging to 14 genera) and 16 branchiopod species (12 genera) (Table 2). Seven of these crustaceans have not previously been recorded from the neighboring territories of NE Siberia, although they are quite widespread through the northern Palaearctic: two calanoids (Acanthodiaptomus denticornis, A. wierzejskii), three cyclopoids (Acanthocyclops venustus, Diacyclops crassicaudis, D. languidoides) and two cladocerans (Eurycercus cf. glacialis, Pleuroxus cf. trigonellus).

Microcrustacean diversity in the studied water bodies was low, and averaged 4.7 species (ranging from 0 to 10). The most common and abundant species in the planktonic samples were the cladocerans Daphnia pulex and Chydorus cf. sphaericus and copepod Heterocope borealis. They occurred in more than 20 localities each (34-45\%). D. middendorfiana, Canthocamptus glacialis, Megacyclops gigas, M. viridis, D. languidoides, Cyclops cf. strenuus and A. venustus were also quite frequent in the samples and occupied in $19-24 \%$ of the investigated water bodies. Almost half of the species ( 9 copepods and 6 cladocerans) were rare and occurred only in one to four water bodies. Our analysis reveals that neither sample-based rarefaction curve nor the best species richness estimator (Chao 1) curve reaches a plateau (Fig. 2A). Therefore, the cladoceran and copepod biodiversity of the region is still incompletely studied, but only few additional taxa could be found here, and a preliminary analysis on the biodiversity could be made in such a situation.

Majority of observed species $(>80 \%)$ has wide Palearctic and Holarctic distribution areas (Table 3). Only five of the species (Heterocope borealis, Leptodiaptomus angustilobius, Canthocamptus glacialis, Daphnia middendorffiana, Eurycercus cf. glacialis) are limited to the Arctic area and are specific only for high latitudes of the northern hemisphere.

The investigated lake analysis revealed that the zooplankton communities of most lakes and ponds are relatively similar both in community structure and species composition. Most of the lakes are characterized by a combination of high abundances of small and large crustaceans. Thus, large copepods like Heterocope borealis and large cladocerans Daphnia pulex and $D$. middendorfiana coexist with small cyclopoid copepods and small chydorids. The same trend was observed for the thermokarst lakes of the Lena River Delta region [Abramova et al., 2017]. The species composition of big foodplain lakes in the Lena River Delta region differs from the small ones. Several rather big lakes of Bykovsky Peninsula with rare species stay a little bit separately too (Fig. 2C).

CCA indicated complex relationships between assemblage composition and habitat variables measured in this study (Fig. 2B, Table 4). Vectors superimposed on the CCA ordination plot graphically represented the correlations between environmental variables and assemblage structures. First two canonical axes explained together $56 \%$ of the response table's inertia. The first axis accounted for $36 \%$ of the total variation in zooplankton assemblage and mainly correlated with water salinity, conductivity; this axis discriminates sharply the two localities with the maximal values of salinity, and with the noticeable role of Eurycercus cf. glacialis and Megacyclops gigas. The salinity varied in the range from 0 to $344 \mathrm{ppm}$; the conductivity ranged from 0 to $688 \mu \mathrm{S}$. The second axis (20\% of the total variation) was mainly related to water temperature (varied from 7.8 to $14.8^{\circ} \mathrm{C}$ ). Along this axis, the stations were arranged gradually from cold-water bodies preferred by Eurytemora lacustris, Pleuroxus trigonellus, Mesocyclops leuckartii and Acroperus harpae, to the warm waters, where Arctodiaptomus bacillifer, Leptodiaptomus angustilobus, Polyphemus cf. pediculus and Bosmi$n a$ cf. longispina were the characteristic species.

The comparison of the samples by the nMDS (Fig. 2C) method does not show a significant separation of the crustacean assemblages in the water bodies of Tiksi vicinities, subjected to a moderate anthropogenic im- 
Table 3. Crustacean species from Bykovsky Peninsula belonging to different groups and biogeographical regions. Таблица 3. Принадлежность видов ракообразных, выявленных на Быковском полуострове, к систематическим группам и биогеографическим регионам.

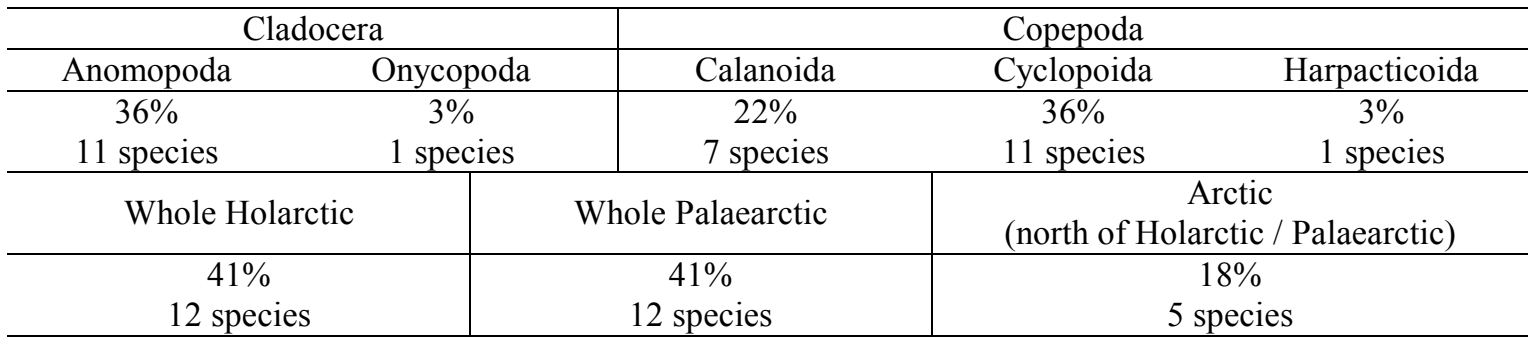

Table 4. Results of the CCA of the taxonomical composition of the microcrustacean communities in the water bodies of Bykovsky Peninsula.

Таблица 4. Результаты ССА таксономического состава микроскопических ракообразных водоемов Быковского полуострова.

\begin{tabular}{|c|c|c|c|c|}
\hline & Axis 1 & Axis 2 & Axis 3 & Axis 4 \\
\hline Eigenvalue & 0.26296 & 0.16155 & 0.1456 & 0.10749 \\
\hline$\%$ & 35.96 & 22.09 & 19.91 & 14.7 \\
\hline Permutation & 0.244 & 0.62 & 0.232 & 0.21 \\
\hline \multicolumn{5}{|c|}{ Intraset correlations of environmental variables with axes } \\
\hline & Axis 1 & Axis 2 & Axis 3 & Axis 4 \\
\hline TEMP & -0.0464 & $0.6161^{*}$ & 0.0327 & 0.0936 \\
\hline $\mathrm{PH}$ & -0.1249 & -0.2199 & -0.2746 & -0.1311 \\
\hline SALT & $0.6529 *$ & -0.2217 & -0.0044 & 0.1837 \\
\hline ORP & -0.0654 & 0.0503 & -0.0820 & -0.3322 \\
\hline COND & $0.6094^{*}$ & -0.2866 & 0.1481 & 0.0243 \\
\hline TDS & $0.5711^{*}$ & -0.2851 & 0.1718 & 0.1831 \\
\hline
\end{tabular}

* verifiable correlations

pact, and in undisturbed water bodies of the Bykovsky Peninsula. The analyzed samples compose a single group, that indicates the high similarity of the Cladocera and Copepoda species complexes in the compared lakes and ponds.

\section{Discussion}

Following recent phylogeographic studies [Crease et al., 2012; Kotov et al., 2016] and conventional taxonomic revisions based mainly on the male characters [Kotov, Bekker, 2016; Garbian et al., 2018], we know that a significant portion of the cladoceran taxa revealed here belong in reality to cryptic species complexes. Therefore, in some cases we cannot make an accurate conclusion on the biogeographic traits of the taxa. But, surprisingly, only D. middendorffiana and Eurycercus cf. glacialis are truly Arctic species, while other Arctic taxa (for example, D. longiremis or $D$. umbra) are absent on Bykovsky Peninsula and neighbouring territory. The species diversity of the area investigated is significantly lower as compared to the total microcrustacean diversity of northeastern Siberia (from the lower reach of the Khatanga River to the Lena River Delta), where 98 species (34 Cladocera and 64 Copepoda) are reported [Pirozhnikov, Shulga, 1957; Colbourne et al., 1998; Abramova, 2003; Abramova et al., 2009, 2017; Sobakina et al., 2009; Vishnyakova, Abramova, 2009; Alekseev, Defaye, 2011; Abramova, Vishnyakova, 2012; Korovchinsky et al., 2012; Frolova et al., 2013, 2016; Nigamatzayanova et al., 2014; Abramova, Zhulay, 2016]. However, several species have not been previously documented from the neighboring regions: Acanthodiaptomus denticornis, Arctodiaptomus wierzejskii, cyclopoid copepods Acanthocyclops venustus, Diacyclops crassicaudis, D. languidoides, Eurycercus cf. glacialis, Pleuroxus cf. trigonellus.

Among the copepods, calanoids $A$. denticornis and A. wierzejskii, recorded for the first time for the NE Siberia, are eurybiotic species [Borutsky et al., 1991; Alekseev, Tsalolikhin, 2010]. Both species are eurythermic and euryhaline, living in freshwater and brackish 
water bodies of various hydrological types and size. $A$. denticornis is also characteristic for mountain lakes at altitudes from 500 to $2500 \mathrm{~m}$ [Borutsky et al., 1991]. A. wierzejskii is distributed in the Palaearctic in a large latitudinal range from the Bolshezemelsky Tundra to Central Asia, and A. denticornis has a Holarctic circumpolar range [Borutsky et al., 1991; Fefilova, 2015]. $A$. venustus and $D$. languidoides, as well as $D$. crassicaudis, are typical for the shallow-water swampy water bodies of the northern regions; to the south these species are found in springs or highland water bodies [Alekseev, Tsalolikhin, 2010; Rylov, 1948]. The first two species are Palearctic, and the third has Holarctic circumpolar range [Alekseev, Tsalolikhin, 2010; Fefilova, 2015].

In general, most taxa recorded in this study are Palearctic or Holarctic with wide latitudinal ranges (Table 3); the latter are confirmed by genetic studies for several members of cryptic species complexes [Crease et al., 2012; Kotov et al., 2016]. Most taxa revealed in the region of this study have wide temperature ranges [Rylov, 1948; Borutsky et al., 1991; Alekseev, Tsalolikhin, 2010; Fefilova, 2015]. The exception is Acanthocyclops venustus, which, although widespread in the Palearctic, is exceptionally cold-water, and is noted only in springs and wells south of the Polar Circle [Alekseev, Tsalolikhin, 2010]. Similar trend in the composition of species areas has been previously noted for plankton crustaceans of other high-altitude regions: Svalbard [Dimante-Deimantovica et al., 2018], Iceland [Novichkova at al., 2014], Shokalsky island [Novichkova, Chertoprud, 2017] and Bering Island [Novichkova, Chertoprud, 2016].

Although the observed crustacean communities are relatively similar to those from the thermokarst lakes of the Lena River Delta, we found some exceptions from this rule. It was previously shown that the small cladocerans Bosmina longirostris and Chydorus sphaericus are typical inhabitants of the large thermokarst lakes on Samoylov Island, together with the larger Daphnia pulex and two Anostraca species, Polyarthemia forcipata and Branchinecta paludosa. Among calanoid copepods, Eudiaptomus graciloides, $L$. angustilobus and $H$. borealis are the dominant copepods in the thermokarst lakes in August [Abramova et al., 2017]. Most of these species are also typical for the observed water bodies of the neighbourhood of Tiksi and Bykovsky Peninsula. Cyclopoid copepods occur in the samples regularly but are much less numerous.

The results of CCA indicated that assemblage structure was correlated mainly with conductivity/salinity and temperature. The correlation between the species composition of the zooplankton community and temperature and mineralization of water for small water bodies of high latitudes is noted in many previous publications [Novichkova, Chertoprud, 2017; Walseng et al., 2018; Jensen et al., 2019]. At the same time, the variability of mineralization of the water body usually correlates with the distance from the sea and/or nesting places of geese on the banks of the water body [Walseng et al., 2018; Jensen et al., 2019, etc.]. In turn, the temperature factor is usually related to the altitude and distance to the focuses of glaciation [Walseng et al., 2018]. It is known that inter-annual temperature fluctuations causing alternation of warm and cold summer seasons in high latitudes can significantly influence the composition of the fauna of Arctic water bodies [Novichkova, Chertoprud, 2017; Dimante-Deimantovica et al., 2018]. Due to the accumulation of the resting stages of microcrustaceans in bottom sediments of water bodies, species of more southern regions may temporarily appear in communities in case of favorable temperature conditions [Novichkova, Chertoprud, 2017].

According to our data, Eurycercus cf. glacialis and Megacyclops gigas are characteristic of water bodies with relatively high mineralization and conductivity (not more than $344 \mathrm{ppm}$ and $688 \mathrm{iS}$, responsibly). Both these species are able to inhabit a wide range of water bodies and have been previously documented for such lakes [Rylov, 1948; Bekker, Kotov, 2012]. The latter species occurs even in brackish-water lakes [Rylov, 1948]. However, variations in the hydrochemical parameters of the comparing lakes of the Bikovsky Peninsula are not significant, all the puddles and lakes considered are freshwater. The range of differences in temperature is also relatively small - only $7{ }^{\circ} \mathrm{C}$. It is necessary to take into account that the temperature of water in Arctic water bodies can vary significantly during the day, which is connected both with their rapid warming due to small depth and mainly dark color of the bottom, and severe weather variability [Grigoriev, 1956]. Relatively warm waters are inhabited by Arctodiaptomus bacillifer, Leptodiaptomus angustilobus, Polyphemus pediculus and Bosmina cf. longispina. Apart from L. angustilobus all these species prefer quite warm water. Thus, the optimum temperature for the development of $P$. pediculus is $17-$ $21{ }^{\circ} \mathrm{C}$ [Butorina, 1971]. Following recent climatic changes $B$. cf. longispina has propagated from temperate latitudes to Arctic water bodies [Walseng et al., 2018]. A. bacillifer is distributed in the wide temperature ranges and inhabits water bodies of both, steppe and tundra zones [Borutsky et al., 1991; Sergeeva, Yevdokimov, 2016]. The only typical coldwater species in this group is L. angustilobus inhabiting tunrda water bodies [Borutsky et al., 1991]. For cold water bodies, Eurytemora lacustris, Pleuroxus trigonellus, Mesocyclops leuckartii and Acroperus harpae are typical. However, only E. lacustris is a real cold-water taxon. This species is considered a 'classical' glacial relict species in central Europe [Maier et al., 2011]. E. lacustris requires cold (around $10{ }^{\circ} \mathrm{C}$ ) and well-oxygenated $\left(>1 \mathrm{mg} \mathrm{O}_{2} \mathrm{~L}^{-1}\right)$ waters [Patalas, Patalas 1966; Kasprzak et al., 2005; Karpowicz, Kalinowska, 2018]. Oppositely, $M$. leuckartii, is relatively warm-water, it develops in $15-20^{\circ} \mathrm{C}$ [Rylov, 1948], but has a wider distribution range - from tropics to Arctic [Fefilova, 2015]. Two cladoceran species (P. trigonellus, A. har- 
pae) inhabit wide temperature range of water bodies, dwelling on the bottom and in the phytal zone [Alekseev, Tsalolikhin, 2010]. Thus, the dominance of certain species in a particular water body in some cases may result from stochastic processes and be determined by the founder effect and subsequent water body monopolization [De Meeester et al., 2002]. Probably, the local dominance of cold-water species in warmed water bodies could be explained by such reasons.

According to the non-metric multidimensional scaling, the species composition of Cladocera and Copepoda does not differ in the water bodies from Tiksi and from Bykovsky Peninsula. The domination structure in the microcrustacean species assemblages of two compared regions is almost similar, while the number of species differs significantly (11 in Tiksi and 29 in Bykovsky Peninsula). The overlap between the species lists of these areas is only $81 \%$. Only two species, Acanthocyclops denticornis and Diacyclops crassicaudis, were found exclusively in the water bodies within the settlement. The reduced species richness and simplification of the species assemblages structure is characteristic for the water bodies exposed to pollution [Walseng et al., 2018]. In general, zooplankton communities of high altitudes are very poor and driven, first of all, by the temperature factor and availability of food resources [Novichkova, Chertoprud, 2017; Walseng et al., 2018; Jensen et al., 2019]. Against this backdrop, a moderate anthropogenic impact has almost no effect on the distribution of dominant microctustacean species, but leads to a significant reduction in taxonomic diversity due to the decrease of the number of rare species.

Acknowledgements. Many thanks to E.I. Izjumova, A.N. Maleeva, O.V. Levochkina, V.V. Skosar', V.E. Tumskoy, A.A. Zharov for their assistance during the works at Bykovsky Peninsula, R.J. Shiel for linguistic corrections in earlier draft. The study of Cladocera is supported by the Russian Science Foundation (grant 18-14-00325).

\section{References}

Abramova E.N. 1996. [Copepoda (Crustacea) of the Lena Delta Reserve] // Gidrobiologicheskie issledovaniya v prirodnykh zapovednikakh. Vol.8. No.3. P.5-16 [in Russian].

Abramova E.N. 2003. Species composition, ecology, population structure and seasonal dynamic of zooplankton from tundra water basins in the Lena Delta // Berichte zur Polar und Meeresforschung. Vol.66. P.96-136.

Abramova E.N., Sokolova V.A. 1999. [On findings and life cycle of Limnocalanus johanseni Marsh, 1920 (Copepoda, Calanoida) over the Lena River Delta] // Zoologicheskiy Zhurnal. Vol.78. No.11. P.1360-1363 [in Russian].

Abramova E., Solov'ev G., Abramova A. 2009. Longterm variability of pelagic fauna in the different lakes in the Lena River Delta. Reports on Polar and Marine Research. Vol.3 P.25-26.

Abramova E., Tuschling K. 2005. A 12-year study of the seasonal and interannual dynamics of mesozooplankton in the Laptev Sea: Significance of salinity regime and life cycle patterns // Global and Planetary Change. Vol.48. No.1-3. P.141-164.

Abramova E., Vishnyakova I. 2012. New data about zooplankton species composition and distribution in the lakes of the Lena
Delta // Berichte zur Polar- und Meeresforschung. Bd.642. P.30-35.

Abramova E., Vishnyakova I., Boike J., Abramova A., Solovyev G., Martynov F. 2017. Structure of freshwater zooplankton communities from tundra waterbodies in the Lena River Delta, Russian Arctic, with a discussion on new records of glacial relict copepods // Polar Biology. Vol.40. No.8. P.1629-1643.

Abramova E.N., Zhulay I.A. 2016. [The occurrence of the new zooplankton species in the Lena River Delta] // Trudy Zoologicheskogo Instituta RAN. Vol.320. No.4. P.473-487 [in Russian].

Alekseev V.R., Defaye D. 2011. Taxonomic differentiation and world geographical distribution of the Eucyclops serrulatus group (Copepoda, Cyclopidae, Eucyclopinae) // Crustaceana Monographs. Vol.16. P.41-72.

Alekseev V.R., Tsalolikhin S.Y. (eds.). 2010. [Guide of freshwater zooplankton and zoobenthos of European Russia. Vol.1. Zooplankton.] Moscow: KMK Sci. Press. 495 p. [In Russian]

Are F., Reimnitz E. 2000. An overview of the Lena River Delta setting: geology, tectonics, geomorphology, and hydrology // Journal of Coastal Research. Vol.16. No.4. P.1083-1093.

Bekker E.I., Kotov A.A. 2012. A revision of the subgenus Eurycercus (Eurycercus) Baird, 1843 emend. nov. (Cladocera: Eurycercidae) in the Holarctic with the description of a new species from Alaska // Zootaxa. Vol.3206. P.1-40.

Behning A.L. 1942. [About the Lena River plankton] // Izveztiya Biologo-Geograficheskogo Nauchno-Issledovatelskogo Instituta pri Vostochno-Sibirskom Gosudarstvennom Universitete. Vol.6. P.217-230 [in Russian].

Bolshiyanov D.Yu., Makarov A.S., Shnayder V., Shtof G. 2013. [Origins and development of the Lena delta]. St. Petersburg: Arctic and Antarctic Research Institute Publishing. 268 p. [In Russian]

Borutsky E.V. 1952. [Crustaceans. Freshwater harpacticoids] // Fauna SSSR. Crustacea. Vol.3. Moscow-Leningrad: AN SSSR Publ. 429 p. [In Russian]

Borutsky E.V., Stepanova L.A., Kos M.S. 1991. [Key to identification of Calanoida from fresh waters]. St. Petersburg: Nauka. 504 p. [In Russian]

Butorina L.G. 1971. [Biology and life cycle of Polyphemus pediculus (L)] // Trudy lnstituta biologii vnutrennikh vod AN SSSR. Vol.21. No.24. P.155-179 [in Russian].

Clarke K.R., Gorley R.N. 2001. Primer, user manual/tutorial, v5 edn. PRIMER-E Ltd, Plymouth.

Clarke K.R., Warwick R.M. 2001. Change in marine communities: an approach to statistical analysis and interpretation. Plymouth Marine Laboratory, Plymouth.

Colbourne J.K., Crease T.J., Weider L.J., Hebert P.D.N., Duferesne F., Hobaek A. 1998. Phylogenetics and evolution of a circumarctic species complex (Cladocera: Daphnia pulex) // Biological Journal of the Linnean Society. Vol.65. No.3. P. 347-365.

Colwell R.K. 2013. EstimateS, Version 9.1: Statistical Estimation of Species Richness and Shared Species from Samples (Software and User's Guide). URL: http://viceroy.eeb.uconn.edu/ estimates/

Crease T.J., Omilian A.R., Costanzo K.S., Taylor D.J. 2012. Transcontinental phylogeography of the Daphnia pulex species complex // PLoS ONE. Vol.7. No.10. e46620. doi:10.1371/ journal.pone. 0046620

Dahms H.-U., Fornshell J.A., Forshnell B.J. 2006. Key to identification of crustacean Nauplii // Organisms Diversity and Evolution. Vol.6. No.1. P.47-56.

De Meester L, Gómez A., Okamura B., Schwenk K. 2002. The Monopolization Hypothesis and the dispersal-gene flow paradox in aquatic organisms // Acta Oecologica. Vol.23. No.3. P. $121-135$.

Dimante-Deimantovica I., Walseng B., Chertoprud E., Novichkova A. 2018. New and previously known species of Copepoda and Cladocera (Crustacea) from Svalbard, Norway - who are they and where do they come from? // Fauna Norvegica. Vol.38. P.18-29.

Fefilova E.B. 2015. [Copepods (Copepoda). Fauna of the European North-East of Russia]. Moscow: KMK Sci. Press. 319 p. [In Russian] 
Frolova L.A., Nazarova L.B., Pestryakova L.A., Herzschuh U. 2013. Analysis of the effects of climate-dependent factors on the formation of zooplankton communities that inhabit arctic lakes in the Anabar River Basin // Contemporary Problems of Ecology. Vol.6. P.1-11.

Frolova L.A., Nigamatzayanova G.R., Pestryakova L.A., Subetto D.A. 2016. [Structural and functional characteristics of zooplankton community of lake Suturuokh (Indigirka River basin eastern Siberia)] // Vodnye resursy: izuchenie i upravlenie. Materialy V Mezhdunarodnoy konferentsii molodykh uchenykh. Vol.2. P.395-400 [in Russian].

Frolova L.A., Nigamatzayanova G.R. 2019. [Structural and functional characteristics of zooplankton communities of thermokarst lakes of Somoilovskii island (Lena Delta, Sakha Republic (Yakutia))] // Uchenye Zapiski Kazanskogo Universiteta. Vol.1. No.1. P. 158-172 [in Russian].

Garibian P.G., Neretina A.N., Klimovsky A.I., Kotov A.A. 2018. A new case of West-East differentiation of the freshwater fauna in Northern Eurasia: the Pleuroxus trigonellus species group (Crustacea: Cladocera: Chydoridae)// Zootaxa. Vol.4532. No.4. P.451-482.

Grigoriev À.À. 1956. [Subarctic. Characterizing of the main types of geographic environment]. Moscow-Leningrad: Geografgis. 223 p. [In Russian]

Hammer Ø., Harper D.A.T., Ryan P.D. 2001. PAST: Paleontological Statistics Software Package for Education and Data Analysis // Palaeontologia Electronica. Vol.4. No.1. P.1-9. http:/ palaeo-electronica.org/2001_1/past/issue1_01.htm

Jensen T., Walseng B., Hessen D.O., Dimante-Deimantovica I., Novichkova A., Chertoprud E., Chertoprud M., Sakharova E., Krylov A., Frisch D., Christoffersen K.S. 2019. Changes in trophic state and biodiversity in high Arctic ponds in response to increasing goose populations // Freshwater Biology. Vol.64. No.7. P.1241-1254. https://doi.org/10.1111/fwb.13299

Karpowicz M., Kalinowska K. 2018. Vertical distribution of the relic species Eurytemora lacustris (Copepoda, Calanoida) in stratified mesotrophic lakes // Biologia (Bratislava). Vol.73. No.1. P.1197-1204.

Kasprzak P., Reese C., Koschel R., Schulz M., Hambaryan I., Mathes J. 2005. Habitat characteristics of Eurytemora lacustris (Poppe, 1887) (Copepoda, Calanoida): the role of lake depth, temperature, oxygen concentration and light intensity // International Review of Hydrobiology. Vol.90. No.3. P.292-309.

Kerer E.F. 1968. [Zooplankton of the flood plain lakes in the lower reaches of the Lena River] // Ucheniye zapizki LGPI. Vol.311. No.3. P.37-60 [in Russian].

Korovchinsky N.M., Kotov A.A., Sinev A.Yu., Bekker E.I. 2012. [Investigations of systematic diversity of Cladocera (Crustacea: Branchiopoda) of the Northern Eurasia - results of recent years] // Krylov A.V. (ed.). Zbornik lektsiy i dokladov mezhdunarodnoi shkoly-konferencii Aktualnye problemy izuchenia rakoobraznykh kontinentalnykh vod. Kostroma: Kostromskoi pechatnyi dom. P.55-72 [in Russian].

Kotov A.A. 2015. A critical review of the current taxonomy of the genus Daphnia O. F. Müller, 1785 // Zootaxa. Vol.3911. No.2. P.184-200.

Kotov A.A., Bekker E.I. 2016. Cladocera: family Eurycercidae (Branchiopoda: Cladocera: Anomopoda) // Dumont H.J. (ed.). Identification guides to the plankton and benthos of inland waters Vol.25. Leiden: Backhuys Publishers, \& Weikersheim: Margraf Publishers. 89 p.

Kotov A.A., Karabanov D.P., Bekker E.I., Neterina T.V., Taylor D.J. 2016. Phylogeography of the Chydorus sphaericus group (Cladocera: Chydoridae) in the Northern Palearctic // PLoS ONE. Vol.11. No.12. e0168711.

Lutsik A.I., Silina N.I., Lutsik N.K. 1981. [About zooplankton and fish of the south-eastern Laptev Sea] // Okeanologya. Vol.21. No.2. P.370-374 [in Russian].

Maier G., Speth B., Arp W., Bahnwart M., Kasprzak P. 2011. New records of the rare glacial relict Eurytemora lacustris (Poppe 1887) (Copepoda; Calanoida) in atypical lake habitats of northern Germany // Journal of Limnology. Vol.70. No.1. P.145-148.
Nigamatzayanova G.R., Frolova L.A., Pestryakova L.A., Ushnitskaya L.A. 2014. [Structure indices of zooplankton communities of Lena Delta river's water bodies] // Nauka i obrazovanie. Vol.4. P.79-83 [in Russian].

Nigamatzyanova G.R., Frolova L.A., Abramova E.N. 2016. Zooplankton spatial distribution in thermokarst lake of The Lena River Delta (Republic of Sakha (Yakutia)) // Research Journal of Pharmaceutical, Biological and Chemical Sciences. Vol.7. No.5. P.1288-1297.

Nikanorov A.M., Bryzgalo V.A., Kosmenko L.S., Reshetnyak O.S. 2011. Anthropogenic transformation of biocenosis structural organization in Lena River mouth area // Water Resources. Vol.38. P.306-314.

Novichkova A.A., Chertoprud E.S. 2016. Freshwater crustaceans (Cladocera, Copepoda) of Bering Island (Commander Islands, Russian Far East): species richness and taxocenes structure // Journal of Natural History. Vol.50. No.21-22. P.1357-1368.

Novichkova A.A., Chertoprud E.S. 2017. Cladocera and Copepoda of Shokalsky Island: new data from Northwest Siberia // Journal of Natural History. Vol.51. No.29-30. P.1781-1793.

Novichkova A.A., Chertoprud E.S., Gísli Mar Gíslason 2014. Freshwater Crustacea (Cladocera, Copepoda) of Iceland: taxonomy, ecology, and biogeography // Polar Biology. Vol.37. P.17551767.

Patalas J., Patalas K. 1966. The crustacean plankton communities in polish lakes // Verhandlungen des Internationalen Verein Limnologie. Vol.16. No.1. P.204-215.

Pirozhnikov P.L., Shulga E.L. 1957. [The main features of the zooplankton of the lower reaches of the Lena River] // Trudy Vsesoyuznogo Gidrobiologicheskogo Obshchestva. Vol.8. P.219-230 [in Russian].

Rylov V.M. 1928. [Materials on the fauna of freshwater copepods (Copepoda, Calanoida) of the Northern Siberia] // Trudy komissii po izucheniyu Yakutskoi ASSR. Vol.11. P.1-32 [in Russian]

Rylov V.M. 1948. [Cyclopoida of the fresh-water] // Fauna of SSSR Crustacea. Vol.2. Moscow-Leningrad: AN USSR Publ. 321 p. [In Russian]

Sars G.O. 1898. The Cladocera, Copepoda and Ostracoda of the Jana expedition // Ezhegodnik zoologicheskogo Muzeja Imperatorskoi Akademii Nauk. Vol.3. P.324-359.

Sergeeva I.V., Yevdokimov N.A. 2016. [Features of ecology of Arctodiaptomus bacillifer Koelben, 1885 (Crustacea, Calanoida) at the Saratov region temporary waterbories] // Agrarny nauchny zhurnal. No.5. P.26-31 [in Russian].

Serkina R.A. 1969. [Plankton and benthos of the Lena Delta and adjacent coastal waters] // Trudy Yakutskogo otdeleniya Sibirskogo nauchno-issledovatel'skogo instituta rybnogo khozyaistva. Vol.3. P.188-196 [in Russian].

Sinev A.Yu. 2002. [A key to identifying cladocerans of the genus Alona (Anomopoda, Chydoridae) from the Russian European part and Siberia] // Zoologicheskiy Zhurnal. Vol.81. No.8. P.926-939 [in Russian].

Sinev A.Yu. 2009. Discrimination between two sibling species of Acroperus (Baird, 1843) from the Palearctic (Cladocera: Anomopoda: Chydoridae) // Zootaxa. Vol.2176. No.1. P.1-21.

Sobakina I.G. 2013. [Zooplankton of lower Yana River] // Ekologiya Rossii: na puti k innovatsiyam. No.7. P.103-106 [in Russian].

Sobakina I.G., Evstigneeva T.D., Sheveleva N.G., Sokolova V.A. 2009. [Fauna of copepods (Copepoda: Calanoida, Cyclopoida, Harpacticoida) of the River Anabar basin] // Problemi regionalnoy ekologii. No.3. P.98-102 [in Russian].

Sobakina I.G., Sokolova V.A., Solomonov N.M. 2009. Contemporary species composition of the Lena Delta river in autumn period // Izvestiya Samarskogo Centra RAN. Vol.1-3. No.11. P. 347-349.

Sorokin Y.I., Sorokin P.Y. 1996. Plankton and Primary Production in the Lena River Estuary and in the south-eastern Laptev Sea // Estuarine, Coastal and Shelf Science. Vol.43. No.4. P.399-418.

Trofimova T.P., Zhirkov I.I., Zhirkov K.I., Sobakina I.G., Ivanov K.P., 2018. [Recent state of the lakes of the Yana River basin] // Vestnik Swvero-Vostochnogo Federal;nogo Universiteta. Nauki o Zemle. No.2(10). P.32-40 [in Russian]. 
Urban V.V. 1949. [Hydrobiologycal investigations in the Lena Delta] // Izvestya Vsesoyuznogo nauchno-issledovatel'skogo instituta ozyornogo i rechnogo rybnogo khozyaistva. Leningrad. Vol.29. P.75-95 [in Russian].

Vekhov N.V. 1989. [Fauna and distributional features of branchiopods and and tadpole shrimps (Crustacea: Anostraca; Notostraca) in the water bodies of the far north of Siberia and Far East] // Izvestiya Sibirskogo Otdeleniya AN SSSR. Vol.3. P.106-110 [in Russian].

Veremeeva A., Gubin S. 2009. Modern tundra landscapes of the Kolyma Lowland and their evolution in the Holocene // Permafrost and Periglacial Processes. Vol.20. No.4. P.399-406.

Virketis M.A. 1932. [New data on zooplankton from the southeastern Laptev Sea] // Issledovaniya morei SSSR. Leningrad. Vol.15. P.105-125 [in Russian].
Vishnyakova I., Abramova E. 2009. [Zooplankton community structure in the polygonal lakes of the south part of the Lena Delta] // Kassens H., Lisitzin A.P., Thiede J. (eds.). Sistema morya Laptevykh i prilegayushchikh morei Arktiki: sovremennoe sostoyanie i istoriya razvitiya. Moscow: Moscow University Press. P.223-236 [in Russian].

Walseng B., Jensen T., Dimante-Deimantovica I., Christoffersen K.S., Chertoprud M., Chertoprud E., Novichkova A., Hessen D.O. 2018. Freshwater diversity in Svalbard; providing baseline data for ecosystems in change // Polar Biology. Vol.41. No.10. P.1995-2005.

Washburn A.L. 1979. Geocryology. A survey of periglacial processes and environments. London: Arnold. 406 p.

Responsible editor V.A. Spiridonov 